\title{
The Border Harms of Human Displacement: Harsh Landscapes and Human Rights Violations
}

\author{
Suzan Ilcan
}

check for updates

Citation: Ilcan, Suzan. 2021. The Border Harms of Human Displacement: Harsh Landscapes and Human Rights Violations. Social Sciences 10: 123. https://doi.org/ 10.3390/socsci10040123

Academic Editors: Linda Briskman and Lucy Fiske

Received: 10 December 2020

Accepted: 24 March 2021

Published: 30 March 2021

Publisher's Note: MDPI stays neutral with regard to jurisdictional claims in published maps and institutional affiliations.

Copyright: (C) 2021 by the author. Licensee MDPI, Basel, Switzerland. This article is an open access article distributed under the terms and conditions of the Creative Commons Attribution (CC BY) license (https:/ / creativecommons.org/licenses/by/ $4.0 /)$.
Department of Sociology and Legal Studies, University of Waterloo, Waterloo, ON N2L 3G1, Canada; suzan.ilcan@uwaterloo.ca

\begin{abstract}
Building on the work of critical migration and border studies, particularly the scholarship on the suffering of displaced people through border-related violence, the article focuses on bordering practices and human rights violations relating to the Syrian civil war. It advances the argument that during peoples' fragmented journeys to seek safety and protection within and outside of Syria, which are often punctuated by stops and starts, they encounter one or more of three kinds of bordering practices - hardening of borders, expansion of borders, and pushbacks—that can injure them and violate international human rights and often the principle of non-refoulement. The article refers to these encounters as the "border harms of human displacement". The analysis emphasizes the experiences of people on the move and the cruelties and spatial violence they endure. The latter include lengthy periods of walking and running, travel across hazardous lands and seas, family separation, state restrictions, and mistreatment by border authorities. Yet, in response to such difficulties, they continue to assert their agency by negotiating bordering practices and harsh landscapes.
\end{abstract}

Keywords: human displacement; human rights; border harm; spatial violence; migrant journeys; Syrian civil conflict

\section{Introduction}

Even though many international human rights agreements allow displaced people seeking safety and protection to find legal protection and material sustenance in a new country, this is not what many displaced people, such as asylum seekers and refugees, experience. While the need for protection may have expanded across regions of the globe, many states have been providing less sanctuary, especially in the Global North, where many governments have been accepting fewer and fewer refugees in recent years (Bose 2020b). Only a small proportion of those refugees seeking protection settle permanently in these countries. Bhambra (2017) emphasizes that Europe, the wealthiest continent in the world, hosts fewer refugees per population than any other. Moreover, the majority of refugees today relocate to neighbouring states, so relatively poor countries accommodate most of them (Briskman 2020). In fact, the Global South is providing most protection for displaced people. Of the over 79.5 million forcibly displaced people worldwide at the end of 2019, approximately 107,800 were actually resettled as refugees (UNHCR 2020). Eighty-five per cent are hosted in developing countries, and 80 per cent of them live in lands with acute food insecurity and malnutrition (UNHCR 2020). Additionally, these countries are providing fewer and more precarious forms of protection to displaced people, such as those from Syria (e.g., Almustafa 2020; Baban et al. 2017; Sanyal 2018). Even 'non-derogable' human rights, such as the right to education, can be and are often denied to displaced people by states that legislate to override international standards (Bilgic et al. 2020), just as national, citizenship, and security priorities can override migrants' rights (Huysmans and Squire 2009).

State and other governing authorities' treatment of displaced people involves not just protecting, receiving, or resettling them, but also bordering practices and their effects. 
Scholars are increasingly seeing borders not as objects—stable territories that delineate physical areas-but as complex social, political, and discursive formations. Bordering practices (including border walls, deportations, regional agreements, pushbacks), as a malleable strategy to control migration, are the product of a network of actors, discourses, policies, infrastructures, and negotiations (e.g., Kallio et al. 2019; Schindel 2019). Their effects can injure, even kill displaced people and violate their human rights.

In this context I pose the following question: how can we better understand the border harms of human displacement for people on the move seeking protection and assess their insights about these experiences? More specifically, how do bordering practices injure displaced people fleeing the Syrian civil conflict and engage them in negotiating harsh landscapes? The analysis below brings attention to displaced peoples' fragmented journeys within and outside of Syria and their border experiences. Their testimonials to me make clear the injuries they have encountered and allow closer scrutiny of the human rights violations, border harms, and 'spatialized forms of violence' (Schindel 2019) underscoring human displacement. Spatialized forms of violence refer to the diverse ways that border regimes can produce violence, such as by restricting the movements of people on the move in search of protection, creating conditions that encourage asylum seekers and other migrants to engage in dangerous and extended journeys, generating landscapes that are 'weaponized' in ways that can cause harm and even death, such as the desert of the USMexican border, and that can, as Schindel stresses, engender other geographies of border enforcement (ibid., p.3).

Scholars of critical migration and border studies have shown that asylum seekers and refugees face an array of bordering practices during their displacement, journeys, and protracted stops, and their prolonged stays in host states (e.g., Briskman 2020; de Vries and Guild 2019; Ilcan 2018; Y1ldiz and Sert 2019). They have also answered crucial questions about border governance and securitization (e.g., Ineli-Ciger 2017; Tazzioli 2017; Walters 2006), and the role of state policy in managing migration (e.g., Carpi and Şenoğuz 2019; Ilcan 2020; Mountz 2020; Weber and Pickering 2011) and border crossings (e.g., Almustafa 2020; Isakjee et al. 2020; Janmyr 2016). The concept of "slow violence" has been used to describe the distress, state controls, regional migration agreements, and related obstacles that plague refugees and other migrants (e.g., Bugge 2019; Coddington 2019; Davies et al. 2017; Mayblin et al. 2020). For example, Davies et al. 2017 speak of "slow violence" vis-à-vis the distress of refugees trapped at European Union (EU) borders who are deliberately exposed to inadequate public health. Similarly, Schindel (2019) emphasizes forms of border violence that involve the political production of exposure to the elements or the "environmental factors such as geography, topography, and weather", which she calls "spatialized slow violence"; the latter are produced through border enforcement in ways that can be invisible, mediated, or structural (ibid., p. 3). More generally, the harms and spatial violence induced through bordering practices have been emphasized by several authors (e.g., Cosello and Mann 2020; Isakjee et al. 2020; Jonsson 2020; Mountz 2013; Schindel 2019), but bordering practices injure displaced people in ways that draw attention to their border experiences, testimonies, and losses, and to violations of human rights, and this subject deserves closer examination.

Building on the work of critical migration and border studies, particularly the scholarship on the suffering of displaced people through border-related violence, the paper focuses on bordering practices and human rights violations relating to the Syrian civil war. This paper proposes that during peoples' fragmented journeys to seek safety and protection within and outside of Syria, which are often punctuated by stops and starts and are rarely known prior to the onset of the journey, they encounter one or more of three kinds of bordering practices-hardening of borders, expansion of borders, and pushbacks-that injure them and violate international human rights and often the principle of non-refoulement. I refer to these situations as the "border harms of human displacement". The analysis emphasizes the experiences of people on the move and their testimonials of border harms during their fragmented journeys. Their accounts reveal variously the partial, locatable, 
or critical knowledge that can illuminate the experiences of people on the move and the cruelties and spatial violence they endure. The latter include lengthy periods of walking and running, travel across hazardous lands and seas, family separation, state restrictions, and mistreatment by border authorities. Yet, in response to such difficulties, they continue to assert their agency by traversing bordering practices.

The analysis draws on policy, media, program, and scholarly documents, and on a selection from fifty-five interviews with Syrians living in Canada and ten interviews with Syrians living in Sweden. The first set of interviews took place in Ontario-in Kitchener, Mississauga, and Toronto-from January 2017 to November 2018, and the second set in Stockholm in July 2016. The interviewees were recruited through existing contacts and the non-random sampling technique of chain-referral or snowball sampling. All participants had departed Syria for nearby countries (Egypt, Jordan, Lebanon, Turkey) and from there to Europe (Greece, Italy, Norway, Sweden) or elsewhere between 2012 and 2017. They include twenty-seven women and thirty-eight men who lived in Syria both prior to and during the civil conflict and were aged between 19 and 63 and from diverse social backgrounds. The majority of them self-identify as Syrian, but several as Kurdish, Palestinian, or Turkmen. All interviews were in-depth and semi-structured and conducted in either Arabic or English in a location of the interviewee's choice. Most lasted between one and two hours and were recorded and later transcribed. All names of participants in this article are pseudonyms.

In the interviews, participants highlighted their forms of displacement, recollections of their lived experiences during the civil conflict, decisions to leave Syria, and their ability to relocate to neighbouring countries as well as to Europe and elsewhere in the face of challenging life conditions, family separations, and bordering practices. Their recollections form a crucial part of their experiences of the border harms of displacement, which reflect not only how they inhabit space but also how they imagine it in the aftermath of their struggles to access safety and protection. Focusing on their experiences enables an understanding of their border encounters and their ability to negotiate border controls and harsh landscapes. Methodologically, I begin from the position that the border harms of displacement discussed in this article transpire from particular governmental approaches to human displacement and the resulting bordering and migration practices, which have unsettled the relationship between displacement and human rights.

The paper consists of three sections. The first explains the links between human displacement, human rights, and migration, especially in the United Nations' Universal Declaration of Human Rights (UDHR 1948) and the 1951 Refugee Convention, which addressed mass displacements caused by the Second World War and still inform human displacement and protection today. The second emphasizes human displacement flowing from the Syrian conflict. It highlights the political landscape of the conflict, internal displacement, and displaced people from Syria navigating bordering practices within Syria and their travels to neighbouring states, such as Jordan, Lebanon, and Turkey, to seek protection. While most migrants have remained in and received some form of protection from those countries, many others resisted Europe's containment policies and fled there, particularly en masse in 2015. The third section focuses on the border harms of human displacement these people faced during the so-called refugee crisis of 2015 in Europe, especially three bordering practices that shaped their experiences, testimonials, and losses: hardening of borders, through border walls and fences, security services, and checkpoints; expansion of borders, particularly through regional agreements and "hotspots"; and pushbacks, most notably unlawful returns of displaced people to neighbouring states. The analysis highlights the resulting border harms and spatial violence inflicted on displaced people: pushing, pulling, or diverting them around geographical areas and towards increasingly precarious border crossings, and subjecting them to state controls and distressing treatment at borders. These situations often restrict movement, violate fundamental rights, and lead to refoulement. 


\section{Human Displacement, Human Rights, and Bordering Practices}

Over a decade ago, Seyla Benhabib insightfully noted that "the language of human rights has become ubiquitous around the world, shaping such nascent transnational institutions as the International Criminal Court, and justifying international interventions to halt genocide" (Benhabib 2008, p. 94). She emphasized the disagreements among scholars and others concerning the nature and scope of "universal human rights," pointing to views of human rights as variously forming "reasonable conditions of world-political consensus" (Martha Nussbaum), demarcating "a minimum standard of well-ordered political institutions for all peoples" (John Rawls), and extending to the longer lists of rights in the UDHR (Benhabib 2008). As a legally non-binding document that has become customary law (Hyndman and Reynolds 2020), the UDHR states that all persons "without distinction of any kind, such as race, colour, sex, language, religion, political or other opinion, national or social origin, property, birth or other status," are entitled to dignified treatment regardless of "the political, jurisdictional, or international status of the country or territory to which a person belongs" (UDHR 1948). In this context, Benhabib emphasizes the role of the UDHR and later international declarations of rights as reflecting the "moral learning experiences" of not only Western humanity but of "humanity at large" (Benhabib 2008, p. 96). She draws attention to how the world wars were fought not only in Europe but also in colonies, in the Middle East, Africa, and Asia. In her words, the "national liberation and anticolonization of struggles of the post-World War II period inspired the principles of self-determination enshrined in these rights documents" (Ibid., p. 96).

The UDHR was followed by the 1951 Refugee Convention, the International Covenant on Civil and Political Rights in 1966, the International Covenant on Economic, Social and Cultural Rights in 1966, and the Convention on the Elimination of All Forms of Discrimination against Women (CEDAW) in 1981. For example, the countries that have signed the 1951 Refugee Convention have legal obligations to arriving asylum seekers and refugees, such as non-refoulement (no return where a person may encounter severe human rights violations, such as arbitrary imprisonment, torture, death) (see, e.g., Briskman and Fiske 2016). These and other human rights agreements convey a universalistic promise and focus on the urgent needs and requirements of individuals (see Banai and Kreide 2017), including those experiencing displacement.

In the migration context, the UDHR and the 1951 Refugee Convention were devised primarily to address masses of displaced persons in postwar Europe (Betts and Loescher 2011). They contained several core beliefs: "that all people are deserving of protection under international law from harm, that they have the right to return to their homes once the conflict ends and that they should not be forced to return if the conditions that displaced them in the first place have not improved" (Bose 2020a, p. 4). Through various organizations, programs, and arrangements, the spirit of these agreements shapes the protection and rights of displaced people today. For example, several organizations that work for migrant and refugee rights operate on the premises of the UDHR's article 14 on the rights of asylum, the 1951 Refugee Convention, or the ILO's conventions (1949 and 1975), which protect migrant workers against labour market exploitation.

Likewise, the essence of human rights principles operates through specific migrant programs, such as the European Council's Tampere Programme of 1999, which aims to protect displaced migrants from smuggling and trafficking, to ensure that migrants have rights to "freedom, security and justice" (Bilgic et al. 2020, p. 11; Collyer 2020), and to serve as a model for "controlling EU borders" (Guiraudon 2020, p. 155). Similarly, the UDHR's human rights principles inform contemporary refugee and migration compacts: the Global Compact on Refugees (GCR), launched in 2018 and signed by 164 states, and the Global Compact for Migration (GCM), developed and signed by 152 countries (Hyndman and Reynolds 2020). More specifically, the GCR uses the 1951 Refugee Convention and the 1967 Protocol to frame its Plan of Action and Comprehensive Refugee Response Framework. However, there are criticisms of these UN agreements. Hyndman and Reynolds (2020) emphasize that GCR suffers from "convention-centrism" (vis-à-vis Europe) and excludes 
south and southeast Asia and Jordan, Lebanon, and Turkey. Peter Nyers stresses that these compacts assume that "state sovereignty is unquestionably the organizing principle of international and domestic politics" (Nyers 2019, p. 176), which raise crucial issues regarding the role of human rights principles.

Scholars have observed that the human rights framework was exclusionary at its post1945 foundation (focused on Europe), that human rights instruments stipulate minimum standards rather than challenging unjust power relations (Basok et al. 2006; Weber et al. 2014), and that access to human rights is uneven at the present (Mayblin et al. 2020). The limited nature of human rights becomes especially discernible in the case of displaced people through, for example, bordering practices. These practices are not simply territorial lines but encompass internal border checks, closures, sieges, walls, pushbacks, deportations, immigration and border policies, and regional initiatives to shape population movements (e.g., Bauder 2016; de Vries and Guild 2019; Karamanidou et al. 2020; Mountz 2020; Parker and Vaughan-Williams 2012; Rumford 2012). They can induce harm and mistreatment in direct or subtle ways and over time violate human rights (e.g., Cuttitta 2018; Jones 2016; Schindel 2019; Walters 2011). The Syrian conflict provides a useful context for studying the border harms of human displacement, the negotiation of bordering practices and harsh landscapes, and human rights violations.

\section{The Syrian Civil Conflict: "The Regime Fired Back, and a Lot of People Got Killed"}

The Syrian conflict commenced in early March 2011 on the heels of the "Arab Spring" with a wave of pro-democracy uprisings in Syria demanding regime change and political reform. It gradually transformed into a brutal conflict that displaced about 13 million people, or over 60 per cent of the country's pre-war population. Almost half of these people, or 5.6 million, are international asylum seekers and refugees residing in neighbouring Lebanon, Jordan, Turkey, Iraq, and Egypt, while 6.1 million are internally displaced and still living in Syria (Valenta et al. 2020). This section highlights the political landscape of the conflict and people leaving their homes and country to escape the conflict. In these processes, we must not overlook displaced peoples' experiences, testimonies, and losses that bear witness to the conflict. Too often their voices have been silenced.

Syria's first protests, inspired by Egyptian and Tunisian protesters, occurred in the impoverished, drought-stricken rural province of Dara'a. Fifteen school children in the city of Dara'a, 13 kilometres north of the border with Jordon, wrote graffiti on the walls of their school, such as: "The people want to bring down the regime." Such a "spectacle" prompted security forces to respond severely. The children were soon arrested by the Moukhabaret (intelligence service) and tortured, and eleven of them were killed by the Syrian military. In response, many people in Dara'a, most of whom belonged to the country's Sunni majority and shared socio-economic grievances, took to the streets to engage in what they called "peaceful protests." The spectacular violence of the regime's response fostered other peaceful protests across the country. As the unrest increased in volume and intensity, the regime responded harshly with police, military, and paramilitary forces, shooting, imprisoning, torturing, and executing protesters, which made fundamental rights a key issue for innumerable people living in Syria.

Based on testimonials I received, many people recalled the public fears of the civil conflict—fears of homes, schools, hospitals, businesses, and neighbourhoods being bombed, of people disappearing and being tortured, raped, and killed, and of the regime's use of border and migration controls in the cities where they lived, such as Aleppo, Dara'a, and Homs (Interviews, Kitchener, Mississauga, and Toronto 2017, 2018). Such conditions prompted many people to relocate within Syria in search of protection, and to nearby countries, which required them to cross borders. For example, Fatima, a thirty-two-yearold mother and care provider, recalled her family's decision to relocate to another town to escape the violence. The relocation was followed by the killing of her husband at a military checkpoint. Her recollection is noteworthy: 
I lost my husband when we migrated to another town [in Syria]. It happened after two months, after we had relocated to a town nearby. I was with my family. We rented a house together... My husband ... was at a checkpoint when he got wounded. He had two people with him. They were in a long line at this checkpoint. They [border security personnel] were taking IDs and checking them. The opposition took advantage of the fact that there was a regime checkpoint and they hit it. The regime fired back, and a lot of people got killed. My husband was one of them. (Interview, Mississauga, 2018)

This incident highlights not just the power relations that underscore border sites (see, e.g., Jones 2016; Weber and Pickering 2011), but also the intensified surveillance and armed attacks there.

A self-identified Palestinian woman, Maryam, emphasized the political tensions in Syria, the loss of home, and family separations. Seeking to avoid harm and violence, she and her family relocated within Syria prior to leaving the country, which involved precarious and protracted journeys in order to reach safety: "We lost everything. We used to live in Yarmuk [district in Damascus]. The armed groups attacked the area in December 2012, so we had to leave. It was impossible for us to stay . . . because the area would be a hot zone and we would be under fire from both sides." During this initial displacement, she recalled her concerns over her three children's safety; her and her family later travelled to the city of Tartous on the Mediterranean coast of Syria in 2012 and stayed for sixteen months and thence to the United Arab Emirates (UAE), where her daughter lived: "Our daughter arranged a visa for us to visit her in the UAE. It was allowed for Palestinians from Syria, who have children in the Emirates, to apply for a visa to visit the Emirates for a certain period. So, we went to the Emirates although my husband was against leaving Syria ... We stayed with our daughter [for] ... four months. And we started considering the idea of coming to Europe" (Interview, Stockholm, 2016).

Although many people became internally displaced during the civil war, many more decided to leave the country through the help of family members and intermediaries. For example, Ahmad, a Syrian father in his forties, who lost three brothers in the conflict and still has one missing, recollected: "I was wanted by the security forces as I had many brothers who were killed in the besieged areas which made my family name blacklisted, like the case of many Syrians." This situation had encouraged him to leave the country: "I heard that a group of my friends were leaving for Egypt in order to travel to Italy. I decided to go with them, but I had to arrange for my departure with a family from the Damascus airport. In order to avoid any problems, I paid someone [an intermediary] the amount of US \$10,000" (Interview, Stockholm, 2016). The interviews and stories of border crossings reveal how the journeys to nearby countries, such as Egypt, Jordan, Lebanon, and Turkey, were initially long and precarious, punctuated by many pauses, and often fraught with much physical harm and spatialized forms of violence.

\section{From Crossing Open Borders to Navigating Harsh Landscapes}

During the early years of the civil conflict, the nearby host countries of Egypt, Jordan, Lebanon, and Turkey opened their borders to displaced people from Syria and often provided them with limited protection and access to basic services (Can 2017; Badalic 2019; Ineli-Ciger 2017). For example, many Syrians first entered Egypt as tourists without the intention of staying for long periods of time (DW 2019). Differently, starting in April 2011, Turkey's new "open-door policy" (Can 2017) made it relatively easy for Syrians to cross into the country. However, by October 2011, instead of making them legal refugees, Turkey enabled all Syrians, Palestinian refugees, and stateless persons in Syria eligible to receive "temporary protection," which provided them with certain rights, such as the right to education, health care, and work, although many face challenges accessing these protection standards (Baban et al. 2017, 2021; Ineli-Ciger 2017). Rima, a thirty-six-year-old former female primary teacher from Qamishli, a city in northeastern Syria on the Syria-Turkey 
border adjoining the city of Nusaybin in Turkey, comments on internal displacement one year into the conflict, while the Turkish border was still open:

People were leaving from Damascus and other parts of Syria. They were scared of the war and so they would come to Qamishli; it was the only escape [route] because it was right on the Turkish border. The Turkish government was protecting its border, but it was also lenient in a way. There were laws and policies of course, but they would know that Syrians were coming so they would let them in. They treated people good at the beginning. So many Syrians were leaving for Turkey at the beginning, more than they did later on. (Interview, Mississauga, 2017)

However, the Turkish government later came to identify its open border policy as an issue as the number of Syrians in Turkey increased to 2.6 million in January 2016. Around this time, entering the country became progressively more difficult as there emerged heightened border security undertaken by actors including the army, gendarmerie, police, and coastguards, and frequent "border closures between Turkey and Syria" (Ineli-Ciger 2017, p. 558). Consequently, many border crossers from Syria sought alternate and irregular routes, which led them to diverse landscapes, fear, and extreme insecurity. For example, Iman, a thirty-eight-year-old self-identified Kurdish woman and former service worker, crossed into Turkey irregularly around this period. She recalled navigating the harsh landscape with her family and an intermediary: "For me, when I went in [crossed the Turkish border], we ran for three hours ... My sister [from Qamishli] was also with me. She had a baby, 7 months old, and a daughter that was 2. I had my twin boys with me, they were 5, a daughter who was 11 , my other son was 10 . Imagine, my sister was holding my kids and running with them. My son was running. I put my niece on my shoulder. Imagine the struggle. There was so much fear" (Interview, Mississauga, 2017). Iman's recollection, which still haunts her today, highlights how border crossers often navigate harsh landscapes and suffer from exhaustion and fear, what Doty (2011) might call the "raw physicality" produced through border enforcement (see also Squire 2014). Iman elaborated on her experiences of spatial violence:

[When] you're walking at night, even the little kids are with you, and they [the smugglers] tell you to keep them quiet. They tell you to give them something to keep them asleep. Because if they would cry, the guards would hear their crying and they would fire. They wouldn't fire on you, but they would fire in the air so that you would stop. They would then take you and investigate you, and either let you in or send you back. But you wouldn't know [what would happen]. So, it was a struggle. My clothes ripped from the barbed wire. My legs got scratched. Most of the people that entered hurt their arms and legs from the barbed wire. When you enter the country, you're so tired from the journey. It's stressful. You're sick. You don't know the language. (Interview, Mississauga, 2017)

Iman and her family entered Turkey after it had started to build a three-metre-high, 910kilometre-long wall along its border with Syria, in the province of Hatay, to keep out refugees and smugglers. This wall is part of an "Integrated Border Security System" that encompasses technological means of control such as fibre-optic sensors and observation balloons (Karamanidou et al. 2020), which aims to prevent human cross-border movements. Some Syrian families have already made their new homes along the border wall, and others are using it to support the planting of food and drying of clothes, and to prop up canvas tents and provisional shelters (Reuters 2020).

When the number of fleeing Syrians became seemingly unsustainable, Jordon, Lebanon, and Turkey gradually began to harden their borders. In mid-2013, Jordan closed all its informal western border crossings, where most entries occurred, from the Dara'a governorate, to all Syrians except the war-wounded (HRW 2015). In October 2014, Lebanese authorities began to limit Syrian entries and "encourage" Syrian refugees to return home ( Badalic 2019; Janmyr 2016). As mentioned earlier, starting in early 2016, Turkey repeatedly closed its border between Turkey and Syria to displaced people from Syria. Reports from 
INGOs, including Amnesty International (AI) and Human Rights Watch (HRW), claim that forced returns of Syrians have occurred on the Turkey-Syria border (Ineli-Ciger 2017).

These and similar bordering practices have prevented displaced people from Syria and other countries from crossing borders lawfully and obtaining legal protection. Such practices violate the covenanted principle of non-refoulement, which protects asylum seekers. Article 33(1) of the 1951 Refugee Convention states: "No Contracting State shall expel or return (refouler) a refugee in any manner whatsoever to the frontiers of territories where his life or freedom would be threatened on account of his race, religion, nationality, membership of a particular social group or political opinion" (UN General Assembly 1951). Although a foundation of the 1951 Refugee Convention is the principle of non-refoulement, Article 33(2) does recognize that there may be certain cases in which an exception to this principle can be lawfully made.

\section{Border Harms and the "European Refugee Crisis"}

While early in the conflict, Syrians received short-term protection from Egypt, Jordan, Lebanon, and Turkey (e.g., Ineli-Ciger 2017; Janmyr 2016; Sanyal 2018), they have since been facing insecure legal status, limited rights, and precarious living, employment, and mobility situations (e.g., Carpi and Şenoğuz 2019; Dağtaş 2018; Ilcan et al. 2018). Moreover, Europe too was introducing harmful migration control initiatives around the same time. While most displaced Syrians have remained in neighbouring countries, many decided to remake their lives in the EU and accordingly exercised their border rights, resisted Europe's containment policies, and headed there, particularly en masse in 2015. This section discusses their experiences of the hardening and extension of borders, pushbacks, and the resulting human rights violations.

In 2015, migration issues took over public debate in Europe. There was a surge of people escaping armed conflicts and even prosecution in Syria and neighbouring countries, but also in Afghanistan, Iraq, and parts of Africa. Over one million undocumented migrants and refugees entered Europe in 2015, more than 800,000 of them through the maritime channel between Turkey and the Greek islands (Carlier et al. 2020). Each day, several thousand migrants were arriving by boat on the Greek islands, often with the help of intermediaries (Gozdziak and Main 2020) or travelling to other places in Europe (see Cosello and Mann 2020; see also UNHCR 2015). Every day other migrants were arriving in southern Europe (UNHCR 2015), some via the 'Balkan route' from Greece, through Serbia, and then either through Hungary into Austria and then Germany, or through Croatia and Slovenia (Isakjee et al. 2020, p. 1763). Of these arrivals, some 50 per cent were Syrian citizens, 20 per cent Afghans, and 7 per cent Iraqis (Korte 2020). Such movements sparked an alleged "European refugee crisis" which was viewed as consisting of several categories of migrants or "mixed migratory flows" (Spathopoulou et al. 2020, p. 1).

The so-called crisis was, as Carlier et al. (2020, p. 37) propose, much more one of governance than of migration, spurring rapid border closures, visa requirements, Operation Sophia, with Frontex and Europol, to block migrants, and the EU-Turkey Statement to keep migrants away from Greece (discussed below). As well, discourses about these people on the move emerged to mollify escalating anti-immigrant and -refugee sentiments (Holmes and Castañeda 2016; Isakjee et al. 2020), highlight 'illegal' border crossings (Geiger and Pécoud 2010; Jeandesboz and Pallister-Wilkins 2014), and stress the need to securitize the EU, and accentuate its sense of territory (Bauder 2016). In other words, the crisis was more about underwriting forms of knowledge to govern migration through binary divisions (e.g., deserving versus undeserving; integration versus segregation) (Crawley and Skleparis 2018; McMahon and Sigona 2018) and to foster the fear of outsiders (see Huysmans 2006), which are facilitated by a multiplicity of migration and border security practices, actors, and technologies. Such practices often lead to the irregular movements of displaced people that require them to engage in circuitous routes and protracted stays to reach their destinations. In this regard, they experience precarious land and sea journeys, which can result in injuries, spatial violence, dehumanization, and the absence of state 
protection. To this end, we now look in turn at the hardening of borders, their expansion, and the pushing back of displaced peoples during the "crisis."

\subsection{The Hardening of Borders: "There Was So Much Fear"}

Around the time of the so-called crisis, many countries in Europe and elsewhere began to harden their borders by building walls and fences, expanding security services, introducing checkpoints, and intensifying surveillance (Bauder 2016; Holmes and Castañeda 2016; Johnson and Jones 2018; Vollmer 2016) to keep out displaced people from Syria and elsewhere. For example, Bulgaria erected a 30-kilometre, four-metre-high wall on its Turkish border (Üstübici and İçduygu 2019) to prevent "illegal crossings." The Hungarian government started building a double fence at its border with Serbia, displaying a symbolic image of "fortress Europe" (Korte 2020). New transit zones at the border held asylum seekers until refoulement, and a multitude of new laws included criminalizing refugees' border crossings (Bender 2020). Other barriers were assembled at Macedonia's border with Greece, Slovenia's with Croatia, and Austria's with Slovenia. Increased border enforcement in the Mediterranean and Aegean Seas reduced sea arrivals of migrants in 2016 to just one third of 2015 figures and tripled the death rate (Washington Post 2016). More subtle but horrific bordering practices were developing, which included banning of sea rescue missions in the Mediterranean (Garelli et al. 2018; Stierl 2018) and allowing boats to sink. Such "violence of inaction and denial" (Davies et al. 2017, p. 1755) clearly devalues some human lives (Mayblin et al. 2020).

The hardening of borders causes harm. Many displaced people confronting it have endured much hardship and violence (see, e.g., Badalic 2019; Davies et al. 2017; Squire 2020). Indeed, often such bordering practices compel alternative and precarious routes, which can expose them to harsh environments, exhaustion, and other forms of spatial violence. One 17-year-old Syrian male, Samir, recalled his temporary stay in Turkey and his 2014 fragmented journey to Europe, aided by intermediaries. A dangerous sea journey took him to a police station on the Greek island Symi:

So, we [Samir and his 19-year-old cousin] stayed in a hotel in Marmaris [Turkey] for three days. Then we went to the harbour as we were planning to leave on a yacht. We were 26 people, including 4 kids ... We were going around in the sea as tourists ... After six hours, we reached an isolated and unpopulated island. The smuggler wanted to put us there. All smugglers do this ... They do this so they can escape and not get caught. Before reaching that island, the Greek [coastal security] appeared. They intercepted our boat. They asked for our passports. The boat driver showed them the fake passports. They were not convinced and asked the driver to follow them. They took us to the Greek island Symi. The captain jumped in the water and we were left with the driver. (Interview, Stockholm, 2016)

Samir recalled the violence on Symi, including how "the Greek [coastal security] got us out of the boat and started to beat the driver, who was Turkish. They kept beating him badly for a long time". Exemplifying his recollection, Samir commented on the confiscation of their passports and mobile phones and sleeping under police control: "We slept on the floor near the harbour, under the control of the police, until noon time. There was not any space at the police station. It was full of Syrians. Then the police told us to book a hotel room on the island and ... to come to the coastal [security] office to take our photos and fingerprints so we can get the Kharti paper [a 6-month permission permit to stay in Greece]".

After being released, Samir and his cousin headed to Athens and hired a smuggler to help them travel to Sweden to join their families. While his cousin made it to Sweden with an intermediary's assistance, Samir was unsuccessful and remained in Greece. Over several months of displacement and family separation, Samir was compelled to use clandestine networks and convoluted routes to get to his destinations. Eventually, with the aid of his mother and another intermediary, he arrived in Sweden by air. 
Around the same time, Maya, a self-identified Palestinian woman from Syria, travelled by boat from Marmaris, Turkey, to Rhodes, Greece, and then to a refugee camp in the Norwegian town of Moss. She experienced exhaustion, mistreatment by security and police personnel, family separation, and confinement in a refugee camp for several months:

We arrived at the island [Rhodes] and it was totally abandoned. There was nothing there. I was so afraid and so tired. I could not catch my breath. I felt the blood stopping in my veins. We had to climb a very steep cliff in order to reach the populated part of the island. We then walked to the nearest house and asked the locals about the police station. The police came and loaded us in a lorry. We were 55 people in one lorry. They took us to a police station where they interrogated us individually ... There was a police officer who kept shouting at us ... On Monday, the police came and took our full fingerprints ... They showed us how to book the tickets for the ferry that will take us to Athens.

In Athens, we stayed at a hotel for 35 Euro per night. My husband's friend sent his passport and his wife's passport to us with someone else. The passports were genuine European passports. We used them to reach Norway ... So, we flew from Athens to Vienna where we spent a night at a hotel ... Then we went from Vienna to Oslo ... At the police station [in Oslo], they took everything from us ... We slept on the floor ... The place was full of people: Palestinians, Syrians, Africans, and other nationalities. We were interrogated by a police officer after we gave them all our identity documents including ... the UNRWA white cards. Then they took us by a bus to a camp in a city called Moss. It is in the south ... I had to stay in the women's section and my husband was with the men. We were separated at this camp for 100 days, three months ... . (Interview, Stockholm, 2016)

The hardening of borders has not only discouraged or prevented many displaced people from reaching the EU, but it has also blocked access to legal protection within Europe. Such limited- or no-entry situations commonly induce much physical harm and spatial forms of violence, encouraging people "towards irregular-and hence more dangerous and costly-routes" (de Vries and Guild 2019, p. 2158; see also de Vries et al. 2016; Tinti and Reitano 2017). Maurice Stierl asserts that over the past five years "European migration policies have turned increasingly restrictive, exacerbating the injurious and deadly violence that we have witnessed already for decades along Europe's external borders" (Stierl 2020, p. 10). The extension of borders is part of these harmful policies.

\subsection{The Extension of Borders: "Abuse, Mislead and Expel"}

The EU has extended its borders by signing agreements and providing incentives to certain governments, such as those in Libya, Morocco, Tunisia, and Turkey, to regulate migration and detain or encamp displaced people heading to Europe (Bose 2020b; Stierl 2020). These arrangements often involve non-EU actors, such as intergovernmental organizations of the UNHCR, the International Organization for Migration (IOM), the International Centre for Migration Policy Development (ICMPD), national agencies, and non-governmental organizations (NGOs), and are implemented via "'informal processes', 'dialogues', and regional consultations" (Karamanidou et al. 2020, p. 13). For example, the EU-Turkey Statement, targeting displaced people from Syria, addresses the increase in asylum and migration into Europe. It aims at decreasing irregular and dangerous sea crossings in the Aegean Sea by making deportation from Greece to Turkey more efficient and by resettling recognized refugees from Turkey to the EU (Tantardini and Tolay 2019). Asylum seekers who have entered Greece irregularly via Turkey would be returned to the latter (Cosello and Mann 2020).

The Statement started with 'one-for-one' resettlement, wherein for every Syrian returned from the Greek islands to Turkey another would be resettled from Turkey to the EU (e.g., Rygiel et al. 2016; Üstübici and İçduygu 2019). It viewed Turkey as a "safe third 
country," even though the country does not give legal refugee status to non-European asylum seekers, and there is a "wealth of evidence about the human rights violations and rule of law challenges in the country" (Carrera and Cortinovis 2020, p. 109). The Statement, particularly its one-for-one resettlement for Syrian refugees, conflicts with international refugee law, discriminates based on country of origin, despite article 3 of the 1951 Refugee Convention (Carrera and Cortinovis 2020), and can allow refoulement.

One thirty-year-old Syrian university student, Nabil, who currently lives in Toronto, recollected: “The EU-Turkey deal ruins lives. It doesn't care about the people who have suffered from the war. It confines people ... . It can make them stay in the same place for a very long time ... One never knows how long it will take for them to receive protection from governments" (Interview, Toronto, 2018). Despite criticism from domestic and international human rights organizations and migration and refugee scholars (e.g., Cosello and Mann 2020; Heck and Hess 2017; Karamanidou et al. 2020), the Statement has developed alongside other EU migration and bordering practices, such as the 'hotspot' approach.

The European Commission in May 2015 presented hotspots as part of the "European Agenda on Migration." As Spathopoulou et al. (2020) emphasize, the Agenda mandates the European Asylum Support Office (EASO) to collaborate "on the ground with frontline Member States to swiftly identify, register and fingerprint incoming migrants," dividing those eligible to apply for asylum from ineligibles slated for deportation (Spathopoulou et al. 2020, pp. 1-2). With the support of EU agencies such as EASO, Europol, and Frontex, the approach entails de-facto detention of migrants and asylum seekers in five hotspots (detention centres) in Greece (Chios, Kos, Leros, Lesvos, and Samos) and five in Italy (Lampedusa, Messina, Pozzallo, Taranto, and Trapani) (see Campesi 2020; DRC 2017; see also ECRE 2017). These centres are bound by the European Convention of Human Rights (ECHR) and international human rights treaties that both Greece and Italy have ratified, namely the 1951 Refugee Convention, the International Covenant on Civil and Political Rights, and the Convention against Torture.

However, these detention centres manage large numbers of displaced people arriving from Syria and elsewhere but exhibit poor construction, repeated overpopulation, inadequate services, frequent violence, and the protracted detention of many people "innocent of any crime, who are kept mostly idle, and whose futures are uncertain" (Carlier et al. 2020, p. 46). Such border zones have become not spaces of transit for displaced people but mechanisms to reject, detain, illegalize, and deport them (de Vries and Guild 2019; Tazzioli 2016), and, I would add, to inflict on them border harm and spatial violence. For example, in the case of Italy, AI (2014) asserts that "there are cases where it's less 'identify, screen and filter' and more a case of 'abuse, mislead and expel'". It has received reliable accounts of coercive methods used by the Italian police to acquire fingerprints, including arbitrary detentions, beatings, electric shocks, sexual humiliation, and other forms of mistreatment. Many displaced people from Syria and elsewhere have faced rejection and deportation and been prevented from accessing legal protection in Europe. The armed conflict and persecution at home have been far less relevant to displaced peoples' everyday experiences than the hotspots that contain them and prepare them for a protracted life of displacement. In Tazzioli's words: "The Hotspot System contributes to enforce forms of containment through mobility that consists in controlling migration by obstructing, decelerating, and troubling migrants' geographies-more than in fully blocking them" (Tazzioli 2017, p. 2764). In this regard, hotspots and other similar containment efforts raise crucial questions about human rights treaties and their (in)ability to protect asylum seekers and refugees from harm and cruelty. Indeed, the language of human rights is being eclipsed by regional migration agreements and border zone measures that govern the movements of people seeking protection. 


\subsection{Pushback Practices: "Migrants Were Slapped and Kicked by the Coastguards"}

Pushback practices, often a key mode of border management and migration control, refer to the irregular returns of displaced people to neighbouring states regardless of individual circumstances, or to their rejection at the border when they seek international protection. Such practices may include returning individuals to countries of war, such as Syria, whether directly or via a third country (AI 2014) and pushing boats back and leaving them stranded at "some wild area of the coast, with little possibility of reaching an inhabited area and looking for help" (Schindel 2019, p. 6). Such harm, violence, and racism have been associated with various agencies, such as Croatian border forces (Isakjee et al. 2020), the Greek Coast Guard (Schindel 2019), Turkish border guards (HRW 2020), and diverse border-island authorities (Mountz 2013).

Around the time of the so-called European refugee crisis, decades of EU migration policy started to dissipate due to fiscal and political predicaments (Mountz 2020) and growing numbers of displaced people from Syria seeking asylum. Several countries pushed back numerous Syrian and other would-be migrants, including Croatia, Greece, Hungary, and Italy. Migrants found themselves in what Mountz calls "revolving doors," "intercepted and sent back repeatedly from Greece to Turkey and from the Mediterranean to detention in Libya, and lost at sea" (Mountz 2020, p. 70). For example, displaced people attempting to pass through Croatia to seek asylum in the EU were "routinely violently 'pushed back' and illegally expelled into Bosnia and Serbia, without having their asylum claims processed" (Isakjee et al. 2020, p. 1763). Likewise, AI (2014) reports that many refugees and other migrants' vessels crossing from Turkey were diverted and disabled by boats carrying Greek officials and towed back to Turkish waters. For example, a 28 -year-old male Syrian described how he and his brother were pushed back to Turkey on 17 November 2013. They were part of a group of 35 people from Syria, including families with children. The group left Kuşadası, Turkey, aboard a plastic boat around 1 a.m., heading for Samos, the closest Greek island to Turkey. The two men relayed their experiences to AI:

At around 2.30 a.m., a grey metallic Greek coastguard vessel stopped them. A second coastguard boat arrived soon afterwards. The refugees and migrants were ordered to board the second vessel. As soon [as] they got on board, the crew switched off all the lights and using just a flashlight, ordered the men to strip and searched them in what they described as "a humiliating way". They and other migrants were slapped and kicked by the coastguards. The coastguard crew took their money, mobile phones and documents. They kept the money and expensive mobile phones and threw everything else, including valuable documents such as passports, into the sea.

At round 4.30 a.m. the coastguards forced them back into the plastic boat and removed the small motor and fuel. They towed the boat for about $30 \mathrm{~min}$ towards Turkey and then abandoned them near Kuşadası. The men said they were picked up by a Turkish vessel about half an hour later. (AI 2014, p. 18)

UNHCR's Greek office reported credible allegations of 152 separate pushbacks in 2013 and 2014 (Breen 2016), and many others towards Turkey have since occurred (e.g., EECRE 2018; The Guardian 2020). Often migrant boats are forced to return to their port of origin or to another destination outside the EU, and people are abandoned to face harsh conditions, such as extreme heat or cold, dangerous seas, and exhaustion. Such border harm and spatial violence violate the European Convention on Human Rights' prohibition on collective expulsions of non-nationals and article 33 of the 1951 Refugee Convention. However, Schindel warns that the 1951 Convention does not prohibit specifically "expulsion of refugees into zones of exposure to environmental dangers or to psycho-physical collapse" (Schindel 2019, p. 6). This situation is disconcerting: most border deaths in Europe are related to increased exposure to environmental conditions (Schindel 2019), which raise crucial questions concerning the border harms of human displacement and the foundering of international human rights agreements. 


\section{Conclusions}

Building on and contributing to the critical migration and border studies scholarship, this article has focused on the relations among human displacement, bordering practices, and human rights violations in the context of the Syrian civil war. It has argued that human rights' limitations become starkly visible when various migration and border control measures restrict access to protection for displaced people, who seek refuge from war and persecution. The article has shown that, due to the civil conflict, displaced people from Syria have embarked on fragmented journeys within and outside that country. Out of necessity, they have navigated hardening and expanding borders and pushbacks, and their testimony has highlighted their experiences concerning the border harms and spatial violence they endured. The latter include lengthy periods of walking and running, travelling across dangerous lands and seas, smugglers' demands, state controls, and illtreatment by border authorities. As long as nation-states and other governing actors endorse injurious border policies and practices and bilateral agreements to avert the movement of displaced people, these situations will continue to devastate the lives of displaced peoples and reflect the breakdown of international human rights agreements. Yet these situations open up different forms of politics that can focus greater attention on migrants' interests, rights, and movements, and the potential of a deeper demand for migrant and social justice.

Funding: This research was funded by a Social Sciences and Humanities Research Council of Canada (SSHRC) Partnership Development grant (2016-2019; \#50210-51359) and a SSHRC Insight grant (2015-2020; \#50656-10041).

Data Availability Statement: Not applicable.

Acknowledgments: A special thank you to the Syrian families for agreeing to participate in this research and for sharing their valuable knowledge, stories, and insights. The fifty-five interviews conducted in Ontario were done with the assistance of MA students. I thank Zainab Abu Alrob, Violette Khammad, and Nour Al Nasser for their participation in interviews and their translations. I wish to thank Manuel Jimenez Bueno and Ali Mostolizadeh for their library research. My gratitude to Maissa Almustafa for providing access to her networks in Stockholm and for her participation in interviews and her translations. The three interviews from Stockholm, of which select quotes are drawn upon in this paper, are part of a larger project funded through my SSHRC Insight grant, with Feyzi Baban and Kim Rygiel. I am grateful to the Special Issue editors and the two anonymous reviewers for their very helpful feedback.

Conflicts of Interest: The author declares no conflict of interest.

\section{References}

Almustafa, Maissaa. 2020. Reframing refugee crisis: A "European crisis of migration" or a "crisis of protection? Environment and Planning C: Politics and Space. [CrossRef]

Amnesty International (AI). 2014. Greece: Frontier of Hope and Fear. Migrants and Refugees Pushed Back at Europe's Border; London: Amnesty International. Available online: https:/ /www.amnesty.org/en/documents/EUR25/004/2014/en/ (accessed on 30 March 2021).

Baban, Feyzi, Suzan Ilcan, and Kim Rygiel. 2017. Syrian refugees in Turkey: Pathways to Precarity, Differential Inclusion, and Negotiated Citizenship Rights. Journal of Ethnic and Migration Studies 43: 41-47. [CrossRef]

Baban, Feyzi, Suzan Ilcan, and Kim Rygiel. 2021. The Precarious Lives of Syrians: Migration, Citizenship, and Temporary Protection in Turkey. Montreal and Kingston: McGill-Queen's University Press.

Badalic, Vasja. 2019. Rejected Syrians: Violations of the principle of 'non-refoulement' in Turkey, Jordan and Lebanon. Dve Domovini: Two Homelands 49: 87-104. [CrossRef]

Banai, Ayelet, and Regina Kreide. 2017. Securitization of migration in Germany: The ambivalences of citizenship and human rights. Citizenship Studies 21: 903-17. [CrossRef]

Basok, Tanya, Suzan Ilcan, and J. Noonan. 2006. Citizenship, human rights, and social justice. Citizenship Studies 10: 267-73. [CrossRef]

Bauder, Harald. 2016. Understanding Europe's refugee crisis: A dialectical approach. Geopolitics, History and International Relations 8: 64-75. 
Bender, Felix. 2020. Abolishing asylum and violating the human rights of refuges. Why is it tolerated? The Case of Hungary in the EU. In Europe and the Refugee Response: A Crisis of Values? Edited by Elżbieta M. Gozdziak, Izabella Main and Brigitte Suter. London and New York: Routledge, pp. 59-73.

Benhabib, Seyla. 2008. The Legitimacy of Human Rights. Daedalus 3: 94-104. [CrossRef]

Betts, Alexander, and Gil Loescher. 2011. Refugees in International Relations. Oxford: Oxford University Press.

Bhambra, Gurminder K. 2017. The current crisis of Europe: Refugees, colonialism, and the limits of cosmopolitanism. European Law Journal 23: 395-405. [CrossRef]

Bilgic, Ali, Das Gasper, and Cathy Wilcock. 2020. A Necessary Complement to Human Rights: A Human Security Perspective on Migration in Europe. Working Paper No. 660. The Hague: International Institute of Social Studies.

Bose, Pablo. 2020a. The shifting landscape of international resettlement: Canada, the US and Syrian refugees. Geopolitics. [CrossRef]

Bose, Pablo. 2020b. Refugee research in the shadow of fear. GeoJournal. [CrossRef] [PubMed]

Breen, Duncan. 2016. Abuses at Europe's borders. Destination: Europe 51: 21-23.

Briskman, Linda, and Lucy Fiske. 2016. Transcending racism in asylum politics in Australia: Quest for social workers. In Anti-Racist Social Work: International Perspectives. Edited by Gurnam Singh and Shepard Masocha. London: Red Globe Press, pp. 95-113.

Briskman, Linda. 2020. The People's Inquiry into detention: Social work activism for asylum seeker rights. Journal of Sociology 56: 100-14. [CrossRef]

Bugge, Marit. 2019. Obedience and dehumanization: Placing the Dublin regulation within a historical context. Journal of Human Rights and Social Work 4: 91-100. [CrossRef]

Campesi, Giuseppe. 2020. Normalising 'the hotspot approach?': An analysis of the Commission's most recent proposals. In 20 Years Anniversary of the Tampere Programme. Edited by S. Carrera, D. Curtin and A. Geddes. Fiesole: Tampere Programme, European University Institute, pp. 93-104.

Can, Şule. 2017. The Syrian Civil War, sectarianism and political change at the Turkish-Syrian border. Social Anthropology/Anthropologie Sociale 25: 174-89. [CrossRef]

Carlier, Jean-Yves, François Crépeau, and Anna Purkey. 2020. From the 2015 European 'Migration Crisis' to the 2018 Global Compact for Migration: A political transition short on legal standards. McGill Journal of Sustainable Development Law 16: 37-81.

Carpi, Estella, and H. Pınar Şenoğuz. 2019. Refugee hospitality in Lebanon and Turkey: On making 'the other'. International Migration 57: 126-42. [CrossRef]

Carrera, Sergio, and Roberto Cortinovis. 2020. EU Asylum policies through the lenses of the UN Global Compact on Refugees. In 20 Years Anniversary of the Tampere Programme. Edited by S. Carrera, D. Curtin and A. Geddes. Fiesole: Tampere Programme and European University Institute, pp. 105-22.

Coddington, Kate. 2019. The slow violence of life without cash: Borders, state restrictions, and exclusion in the U.K. and Australia. Geographical Review 109: 527-43. [CrossRef]

Collyer, Michael. 2020. 20 years of 'partnership with countries of origin and transit. In 20 Years Anniversary of the Tampere Programme. Edited by S. Carrera, D. Curtin and A. Geddes. Fiesole: European University Institute, pp. 173-82.

Cosello, Cathryn, and Itamar Mann. 2020. Border Justice: Migration and Accountability for Human Rights Violations. German Law Journal 21: 311-34. [CrossRef]

Crawley, Heaven, and Dimitris Skleparis. 2018. Refugees, migrants, neither, both: Categorical fetishism and the politics of bounding in Europe's "migration crisis". Journal of Ethnic and Migration Studies 44: 48-64. [CrossRef]

Cuttitta, Paolo. 2018. Delocalization, Humanitarianism, and Human Rights: The Mediterranean Border Between Exclusion and Inclusion. Antipode 50: 783-803. [CrossRef]

Dağtaş, Seçil. 2018. Inhabiting difference across religion and gender: Displaced women's experiences at Turkey's border with Syria. Refuge 34: 50-59. [CrossRef]

Danish Refugee Council (DRC). 2017. Fundamental Rights and the EU Hotspot Approach. Copenhagen 281: 29.

Davies, Thom, Arshad Isakjee, and Surindar Dhesi. 2017. Violent inaction: The necropolitical experience of refugees in Europe. Antipode 49: 1263-84. [CrossRef]

de Vries, Leonie Ansems, and Elspeth Guild. 2019. Seeking refuge in Europe: Spaces of transit and the violence of migration management. Journal of Ethnic and Migration Studies 45: 2156-66. [CrossRef]

de Vries, Leonie, Sergio Carrera, and E. Guild. 2016. 'Documenting the Migration Crisis in the Mediterranean Spaces of Transit, Migration Management and Migrant Agency'. CEPS Papers in Liberty and Security in Europe. CEPS. Available online: https:/ / www.ceps.eu/system/files/LSE\%20No\%2094\%20DocumentingMigration.pdf (accessed on 30 March 2021).

Deutsche Welle (DW). 2019. Is Egypt using Syrian refugees as a bargaining chip with Europe? Radio. Romana Lenz. June 17. Available online: https:/ / www.dw.com/en/is-egypt-using-syrian-refugees-as-a-bargaining-chip-with-europe/a-49237428 (accessed on 30 March 2021).

Doty, Roxanne Lynn. 2011. Bare life: Border-crossing deaths and spaces of moral alibi. Environment and Planning D: Society and Space 29: 599-612. [CrossRef]

European Council of Refugees and Exiles (ECRE). 2017. New updates on the refugee hotspots in Italy and Greece. ECRE News, July 7.

European Council of Refugees and Exiles (ECRE). 2018. Human Rights Watch report: Push backs of Syrian refugees by Turkey. ECRE News, March 30. 
Garelli, Glenda, Charles Heller, Lorenzo Pezzani, and Martina Tazzioli. 2018. Shifting bordering and rescue practices in the central Mediterranean Sea, October 2013-October 2015. Antipode 50: 813-21. [CrossRef]

Geiger, Martin, and Antoine A. Pécoud. 2010. The politics of international migration management. In The Politics of International Migration Management. Edited by M. Geiger and A. Pécoud. London: Palgrave Macmillan, pp. 1-20.

Gozdziak, Elzbieta Maria, and Izabella Main. 2020. European norms and values and the refugee crisis: Issues and challenges. In Europe and the Refugee Response: A Crisis of Values? Edited by Elżbieta M. Gozdziak, Izabella Main and Brigitte Suter. London and New York: Routledge, pp. 1-11.

Guiraudon, Virginie. 2020. 20 years after Tampere's Agenda on 'Illegal Migration': Policy continuity in speike of unintended consequences. In 20 Years Anniversary of the Tampere Programme. Edited by S. Carrera, D. Curtin and A. Geddes. Fiesole: European University Institute, pp. 147-56.

Heck, Gerda, and Sabine Hess. 2017. Tracing the effects of the EU-Turkey Deal: The momentum of the multi-layered Turkish border regime. Movements 3: 35-57.

Holmes, Seth, and Heide Castañeda. 2016. Representing the 'European refugee crisis' in Germany and beyond: Deservingness and difference, life and death. American Ethnologist 43: 12. [CrossRef]

Human Rights Watch (HRW). 2015. Jordon: Syrians Blocked, Stranded in Desert. June 3. Available online: https:/ /www.hrw.org/ news / 2015/06/03/jordan-syrians-blocked-stranded-desert (accessed on 30 March 2021).

Human Rights Watch (HRW). 2020. Greece: Violence against Asylum Seekers at Border. March 17. Available online: https:/ /www.hrw. org/news/2020/03/17/greece-violence-against-asylum-seekers-border (accessed on 30 March 2021).

Huysmans, Jef, and Vicki Squire. 2009. 'Chapter 15: Migration and Security'. In The Routledge Handbook of Security Studies. Edited by Myriam Dunn Cavelty and Victor Mauer. London: Routledge.

Huysmans, Jef. 2006. The Politics of Insecurity: Fear, Migration and Asylum in the EU. London: Routledge.

Hyndman, Jennifer, and Johanna Reynolds. 2020. Beyond the Global Compacts: Re-imagining protection. Refuge 36: 66-74. [CrossRef]

Ilcan, Suzan. 2020. The borderization of waiting: Negotiating borders and migration in the 2011 Syrian Civil Conflict. Environment and Planning C: Politics and Space. [CrossRef]

Ilcan, Suzan, Kim Rygiel, and Feyzi Baban. 2018. The ambiguous architecture of precarity: Temporary protection, everyday living, and migrant journeys of Syrian refugees. International Journal of Migration and Borders 4: 51-70. [CrossRef]

Ilcan, Suzan. 2018. Fleeing Syria-Border-crossing and struggles for migrant justice. In Mobilities, Mobility Justice, and Social Justice. Edited by David Butz and Nancy Cook. London: Routledge.

Ineli-Ciger, Meltem. 2017. Protecting Syrians in Turkey: A Legal Analysis. International Journal of Refugee Law 29: 555-79. [CrossRef]

Isakjee, Arshad, Thom Davies, Jelena Obradovic-Wochnik, and Karolína Augustova. 2020. Liberal violence and the racial borders of the European Union. Antipode. [CrossRef]

Janmyr, Maja. 2016. Precarity in exile: The legal status of Syrian refugees in Lebanon. Refugee Survey Quarterly 35: 58-78. [CrossRef]

Jeandesboz, Julien, and Polly Pallister-Wilkins. 2014. Crisis, enforcement and control at the EU borders. In Crisis and Migration: Critical Perspectives. Edited by A. Lindley. London: Routledge, pp. 115-35.

Johnson, Corey, and Reece Jones. 2018. The biopolitics and geopolitics of border enforcement in Melilla. Territory, Politics, Governance 6: 61-80. [CrossRef]

Jones, Reece. 2016. Violent Borders: Refugees and the Right to Move. New York: Verso.

Jonsson, Stefan. 2020. A society which is not: Political emergence and migrant agency. Current Sociology 68: 204-22. [CrossRef]

Kallio, Kirsi, Jouni Hakli, and Elisa Pascucci. 2019. Refugeeness as political subjectivity: Experiencing the humanitarian border. Environment and Planning: Politics and Space. [CrossRef]

Karamanidou, Lena, Bernd Kasparek, and Sabine Hess. 2020. Border Management and Migration Control—Comparative Report. Global Migration: Consequences and Responses-Working Paper Series. RESPOND. [CrossRef]

Korte, Kristina. 2020. 'Who is the animal in the zoo?' Fencing in and fencing out at the Hungarian-Serbian Border. A qualitative case study. Journal of Borderlands Studies. [CrossRef]

Mayblin, Lucy, Mustafa Wake, and Mohsen Kazemi. 2020. Necropolitics and the slow violence of the everyday: Asylum seeker welfare in the postcolonial present. Sociology 54: 107-23. [CrossRef]

McMahon, Simon, and Nando Sigona. 2018. Navigating the Central Mediterranean in a Time of 'Crisis': Disentangling Migration Governance and Migrant Journeys. Sociology 52: 497-514. [CrossRef]

Mountz, Alison. 2013. Shrinking spaces of asylum: Vanishing points where geography is used to inhibit and undermine access to asylum. Australian Journal of Human Rights 19: 29-50. [CrossRef]

Mountz, Alison. 2020. The Death of Asylum: Hidden Geographies of the Enforcement Archipelago. Minnesota: University of Minnesota Press.

Nyers, Peter. 2019. Humanitarian hubris in the global compacts on refugees and migration. Global Affairs 5: 171-78. [CrossRef]

Parker, Noel, and Nick Vaughan-Williams. 2012. Critical border studies: Broadening and deepening the 'lines in the sand' agenda. Geopolitics 17: 727-32. [CrossRef]

Reuters. 2020. For Syrians fleeing Idlib, Turkish border wall becomes symbol of their plight. Khalil Ashawi. February 26. Available online: https:/ / www.reuters.com/article/us-syria-security-wall-idUSKCN20K2MQ (accessed on 15 March 2021).

Rumford, Chris. 2012. Towards a multiperspectival study of borders. Geopolitics 17: 887-902. [CrossRef]

Rygiel, Kim, Feyzi Baban, and Suzan Ilcan. 2016. The Syrian refugee crisis: The EU-Turkey 'deal' and temporary protection. Global Social Policy 16: 315-20. [CrossRef] 
Sanyal, Romola. 2018. Managing through ad hoc measures: Syrian refugees and the politics of waiting in Lebanon. Political Geography 66: 67-75. [CrossRef]

Schindel, Estela. 2019. Death by 'nature': The European border regime and the spatial production of slow violence. EPC: Politics and Space. [CrossRef]

Spathopoulou, Aila, Anna Carastathis, and Myrto Tsilimpounidi. 2020. 'Vulnerable refugees' and 'voluntary deportations': Performing the Hotspot, embodying its violence. Geopolitics. [CrossRef]

Squire, Vicki. 2014. Desert 'trash'. Posthumanism, border struggles, and humanitarian politics. Political Geography 39: 11-21. [CrossRef]

Squire, Vicki. 2020. Europe's Migration Crisis: Border Deaths and Human Dignity. Cambridge: Cambridge University Press.

Stierl, Maurice. 2018. Migrant Resistance in Contemporary Europe. London: Routledge.

Stierl, Maurice. 2020. Do no harm? The impact of policy on migration scholarship. EPC: Politics and Space. [CrossRef]

Tantardini, Michele, and Juliette Tolay. 2019. Does performance matter in migration governance? The case of the 2016 EU-Turkey Statement. International Journal of Public Administration. [CrossRef]

Tazzioli, Martina. 2016. Concentric Cages: The Hotspots of Lesvos after the EU-Turkey Agreement. OpenDemocracy. May 20. Available online: https: / / www.opendemocracy.net/en/mediterranean-journeys-in-hope/concentric-cages-hotspots-of-lesvos-after-euturkey-/ (accessed on 15 March 2021).

Tazzioli, Martina. 2017. Containment through mobility: Migrants' spatial disobediences and the reshaping of control through the hotspot system. Journal of Ethnic and Migration Studies 44: 2764-79. [CrossRef]

The Guardian. 2020. Greece faces legal action over alleged expulsion of Syrians to Turkey. Katy Falon. November 17. Available online: https: / / www.theguardian.com/global-development/2020/nov/17/greece-faces-legal-action-over-alleged-expulsionof-syrian-to-turkey (accessed on 30 March 2021).

Tinti, Peter, and Tuesday Reitano. 2017. Migrant, Refugee, Smuggler, Savior. Oxford: Oxford University Press.

UN General Assembly. 1951. Convention Relating to the Status of Refugees. July 28. Available online: http://www.refworld.org/ docid/3be01b964.html (accessed on 30 March 2021).

UNHCR. 2015. Over One Million Sea Arrivals Reach Europe in 2015. December 30. Available online: https:/ / www.unhcr.org/uk/ news / latest/2015/12/5683d0b56/million-sea-arrivals-reach-europe-2015.html (accessed on 15 March 2021).

UNHCR. 2020. Figures at a Glance. June 18. Available online: https:/ / www.unhcr.org/ph/figures-at-a-glance (accessed on 15 March 2021).

UDHR. 1948. University Declaration of Human Rights. Paris: United Nations General Assembly, December 10.

Üstübici, Ayşen, and Ahmet İçduygu. 2019. Border closures and the externalization of immigration controls in the Mediterranean: A comparative analysis of Morocco and Turkey. New Perspectives on Turkey 60: 179-202. [CrossRef]

Valenta, Marko, Jo Jakobsen, Drag Zuparic-Iljic, and Hariz Halilovich. 2020. Syrian refugee migration, transitions in migrant statuses and future scenarios of Syrian mobility. Refugee Survey Quarterly 39: 153-76. [CrossRef]

Vollmer, Bastian. 2016. New narratives from the EU external border-Humane refoulement? Geopolitics 21: 717-41. [CrossRef]

Walters, William. 2006. Borders/Control. European Journal of Social Theory 9: 187-203. [CrossRef]

Walters, William. 2011. Foucault and frontiers: Notes on the birth of the humanitarian border. In Governmentality: Current Issues and Future Challenges. Edited by Ulrich Brockling, Susanne Krasmann and Thomas Lemke. New York: Routledge, pp. 138-64.

Washington Post. 2016. Fenced Out: A New Age of Walls: Episode 2. Samuel Granados, Zoeann Murphy, Kevin Schaul and Anthony Faiola. October 14. Available online: https://www.washingtonpost.com/graphics/world/border-barriers/europe-refugeecrisis-border-control/ (accessed on 15 March 2021).

Weber, Leanne, and Sharon Pickering. 2011. Globalization and Borders: Death at the Global Frontier. Basingstoke: Palgrave Macmillan.

Weber, Leanne, Elaine Fishwick, and Marinella Marmo. 2014. Crime, Justice and Human Rights. Houndmills: Palgrave Macmillan.

Yıldız, Uğur, and Deniz Sert. 2019. Dynamics of mobility-stasis in refugee journeys: Case of resettlement from Turkey to Canada. Migration Studies, 1-20. [CrossRef] 